\title{
Identification of sap-feeder instars in Angelabella tecomae Vargas \& Parra (Lepidoptera, Gracillariidae) feeding on Tecoma fulva fulva (Bignoniaceae)
}

\author{
José Storey-Palma ${ }^{1}$, Hugo Benítez ${ }^{2,3}$, Luis E. Parra ${ }^{4}$ \& Héctor A. Vargas ${ }^{1}$
}

1Departamento de Recursos Ambientales, Facultad de Ciencias Agronómicas, Universidad de Tarapacá, Casilla 6-D, Arica, Chile.
eljose49@hotmail.com; havargas@uta.cl
${ }^{2}$ Faculty of Life Sciences, The University of Manchester, Manchester M13 9PT, United Kingdom. hugo.benitez@postgrad.manchester.ac.uk
${ }^{3}$ Instituto de Alta Investigación, Universidad de Tarapacá, Casilla 7-D Arica Chile
${ }^{4}$ Departamento de Zoología, Facultad de Ciencias Naturales y Oceanográficas, Universidad de Concepción, Casilla 160-C, Concepción, Chile.
luparra@udec.cl ABSTRACT. Identification of sap-feeder instars in Angelabella tecomae Vargas \& Parra (Lepidoptera, Gracillariidae) feeding on
Tecoma fulva fulva (Bignoniaceae). The number of sap-feeding instars of the leaf-miner Angelabella tecomae Vargas \& Parra, 2005
was determined by measuring the head capsule exuviae collected from mines $(\mathrm{n}=125)$ on the shrub Tecoma fulva fulva D. Don
(Bignoniaceae) in the Azapa Valley, northern Chile. Sap-feeding larvae went through four instars in 120 occasions while five larvae
went through five instars. The possible causes for this variation and the usefulness of this tool for future studies are discussed. KEYWORDS. Head capsule width; hypermetamorphosis; larval biometry; leaf-miner.

RESUMO. Identificação de ínstares sugadores de Angelabella tecomae Vargas \& Parra (Lepidoptera, Gracillariidae) em Tecoma fulva fulva (Bignoniaceae). O número de ínstares sugadores do minador de folhas Angelabella tecomae Vargas \& Parra, 2005 foi determinado mediante a coleta de exúvias de cápsulas cefálicas de larvas sugadoras em minas $(\mathrm{n}=125)$ do arbusto Tecoma fulva fulva D. Don (Bignoniaceae), no vale de Azapa, norte do Chile. A larva passou por quatro ínstares em 120 ocasiões, e por cinco ínstares, em outras cinco. As possíveis causas da variação e a utilidade da ferramenta para futuros estudos são discutidos.

PALAVRAS-CHAVE. Biometria larval; hipermetamorfose; largura da cápsula cefálica; minador de folhas.

Gracillariidae is the most diverse among the families of plant-mining Lepidoptera (De Prins \& De Prins 2005). The larvae of these micro-moths undergo a hypermetamorphic development (Kumata 1978; Davis 1987; Davis \& Robinson 1998) and are the only lepidopterans with sap-feeder larvae (Davis 1987).

Angelabella tecomae Vargas \& Parra, 2005 is a gracillariid moth described from the Azapa Valley, Arica Province, northern Chile, whose larvae are leaf-miners primarily in leaflets of the native shrub Tecoma fulva fulva D. Don (Bignoniaceae) (Vargas \& Parra 2005; Vargas 2010). According to Vargas \& Parra (2005), the hypermetamorphic development of $A$. tecomae includes two larval forms, both endophytics: the early form (sap-feeder) has well developed and specially adapted mandibles to tear cells and release their cellular content, which is subsequently sucked; the subsequent form (spinning larva) is characterized by an extreme reduction of the mouthparts, except the spinneret, which is used for build the pupal chamber inside the leaflet, where the pupa remains until adult emergence.
Leaf-miner insects are adequate subjects for many ecological studies because conspicuous traces of their activities are left on the plant throughout its life cycle (Queiroz 2002). Instar number determination and the adequate identification of each instar may be key aspects when some field biology studies are undertaken (Daly 1985). Feeding is restricted to the sap-feeding instars during the larval development of $A$. tecomae. Thus, a detailed knowledge of the life history of the sap-feeding phase is important for planning ecological studies involving this leaf-miner and its host plant. The objective of the present study was to determine the number and provide a morphometric tool to identify the sap-feeding instars of A. tecomae on T. fulva fulva.

Samples were taken from a population thriving in the Azapa Valley, Arica Province, northern Chile, in July and August 2009. Leaflets of T. fulva fulva mined by A. tecomae were collected. Subsequently, the mines were dissected and the number of head capsule exuviae was recorded. Collections of exuviae were restricted to mines either with last instar sap-feeding larvae or with recently molted spinning 
larvae. This method is equivalent to rearing exophytic insects and recording each molt. Then, each instar is indicated by one exuvia inside the mine. The maximum width of each head capsule exuvia was measured using a graduate ocular attached to a stereomicroscope. Each instar was characterized by the mean, range, standard deviation and confidence intervals at 95\%; and the growth rate between consecutive instars was calculated. A Student's t-test was carried out for mean comparisons. Calculations were performed with QuickCalcs, available at http://www.graphpad.com/ quickcalcs/index.cfm. The number of instars and the respective mean values were adjusted to the function $y=a^{\wedge} b x$ using the least squares method. The respective linear regression analysis was carried out with Microsoft Office Excel 2007.

Out of 125 mines examined, the larva went through four instars in $120(96 \%)$ cases (Table I) while five larvae (4\%) went through five instars.

Table I. Head capsule width (mm) of sap-feeding larvae of Angelabella tecomae going through four instars on Tecoma fulva fulva in the Azapa Valley, Arica, Chile. (SD) Standard deviation, (CI) confidence intervals at $95 \%,(\mathrm{GR})$ growth rate.

\begin{tabular}{lcccc}
\hline & \multicolumn{4}{c}{ Instar number } \\
\cline { 2 - 5 } & 1 & 2 & 3 & 4 \\
\hline Mean & 0.1190 & 0.1673 & 0.2327 & 0.3313 \\
$\mathrm{~N}$ & 120 & 120 & 120 & 120 \\
Range & $0.11-0.12$ & $0.15-0.18$ & $0.20-0.25$ & $0.28-0.38$ \\
SD & 0.0030 & 0.0079 & 0.0096 & 0.0125 \\
CI & $0.1185-0.1195$ & $0.1658-0.1686$ & $0.2310-0.2344$ & $0.3290-0.3335$ \\
GR & & 1.41 & 1.39 & 1.42 \\
\hline
\end{tabular}

Head capsule width is frequently used for instar determination in insects (Daly 1985), and many aspects regarding population dynamics of insects may be accurately known if this information is available (Queiroz 2002; Alvan-Aguilar \& Hamada 2003; Guillén \& Heraty 2004). Obviously, the reconstruction of the life history of insects based on measurements of head width will be more accurate and easier if the number of instars is more constant at species level. Nevertheless, as reported here for A tecomae, intra-specific variation in the number of instars has been documented for many insects (Esperk et al. 2007), including some Gracillariidae (Wagner et al. 2000; Guillén \& Heraty 2004).

Esperk et al. (2007) have indicated that many factors could be explaining variations in the number of instars, such as temperature, photoperiod, quality and quantity of food, humidity, population density and sex. Interestingly, a lower growth rate was found in A. tecomae when the sap-feeder went through five instars, which was reflected in smaller head widths for the same number of molts when comparing with a larva going through four instars. Specifically, the head width of the third instar of larvae passing through five instars (mean: $0.198 \mathrm{~mm}$ ) was smaller than the third instar of larvae passing through four instars (mean: $0.2327 \mathrm{~mm})(\mathrm{t}=8.0216 ; \mathrm{DF}=123 ; \mathrm{P}<0.0001)$. On the other hand, the head width was not different among fourth instar larvae going through five instars and third instar larvae going through four instars $(\mathrm{t}=1.2252$; $\mathrm{DF}=123 ; \mathrm{P}=$ 0.2228 ). Furthermore, differences were not found for head width of last instars, regardless of the number of instars $(\mathrm{t}=$ $0.8305 ; \mathrm{DF}=123 ; \mathrm{P}=0.4079$ ). Thus, one could infer that in some cases the larva needs one additional molt to compensate the poor development in early instars. However, the underlying factors determining this pattern remain unknown.

Great variations in the growth rate, as here observed in larvae passing through five instars, are not expected according to the Brooks-Dyar rule (Daly 1985). Moreover, the frequency of four $(\mathrm{n}=120)$ instar larval developments was greatly higher than that of the five $(n=5)$ instar larval development. Both fates are indicating that the basic number of instars in A. tecomae is four. Thus, the presence of five instars should be understood as an atypical situation. The following exponential growth equation was adjusted for larvae going through four instars: $\mathrm{y}=0.0846 \mathrm{e}^{\wedge} 0.34 \mathrm{x} ; \mathrm{n}=480 ; \mathrm{r}=$ $0.99 ; \mathrm{p}<0.0001$.

Due to the low frequency of variation in the number of instars here documented for A. tecomae (4\%), accurate instar identifications of field collected samples based on measurements of head capsules may be undertaken in more than $95 \%$ of the cases, making it an adequate tool for reach the goals of many field studies involving the system $A$. tecomaeT. fulva fulva.

\section{ACKNOWLEDGEMENTS}

We thank Fiorella Vallebuona for her help with the statistical analysis and Bernard Landry for checking the English version. A preliminary version of this manuscript was improved by valuable comments and suggestions from two anonymous referees. This study was supported by Project DIEXA-UTA 9712-11, from Universidad de Tarapacá, Arica, Chile.

\section{REFERENCES}

Alvan-Aguilar, M. A \& H. Hamada. 2003. Larval biometry of Simulium rubrithorax (Diptera: Simuliidae) and size comparison between populations in the States Minas Gerais and Roraima, Brazil. Memórias do Instituto Oswaldo Cruz 98: 507-511.

Daly, H. V. 1985. Insect morphometrics. Annual Review of Entomology 30: $415-438$.

Davis, D. R. 1987. Gracillariidae, p. 372-374. In: F. W. Stehr (ed.). Immature Insects, vol. 1, Dubuque, Kendall/ Hunt Publishing Company, $754 \mathrm{p}$.

Davis, D. R.\& G. S. Robinson. 1998. The Tineoidea and Gracillarioidea, p. 91-117. In: N. P. Kristensen. (Ed.). Handbook of Zoology, Lepidoptera, Moths and Butterflies, vol. 1: Evolution, Systematics, and Biogeography. Berlin \& New York, Walter de Gruyter, 491 p.

De Prins, W \& J. De Prins. 2005. Gracillariidae (Lepidoptera). In: B. Landry (ed.), World Catalogue of Insects. vol. 6, Stenstrup, Apollo Books, $502 \mathrm{p}$.

Esperk, T.; T. Tammaru \& S. Nylin. 2007. Intraspecific variability in number of larval instars in insects. Journal of Economic Entomology 100: $627-645$. 
Guillén, M. \& J. M. Heraty. 2004. Instar differences in Marmara gulosa (Lepidoptera: Gracillariidae). Annals of the Entomological Society of America 97: 1227-1232.

Kumata, T. 1978 A new stem-miner of alder in Japan, with a review of the larval transformation in the Gracillariidae (Lepidoptera). Insecta Matsumurana new series 13: 1-27.

Queiroz, J. M. 2002. Distribution, survivorship and mortality sources in immature stages of the neotropical leaf miner Pachyschelus coeruleipennis Kerremans (Coleoptera: Buprestidae). Brazilian Journal of Biology 62: 69-76.
Vargas, H. A. 2010. Angelabella tecomae (Lepidoptera: Gracillariidae): an exotic hostplant in northern Chile and first record from Peru. Revista Colombiana de Entomología 36: 340-341.

Vargas, H. A \& L. E. Parra. 2005. Un nuevo género y una nueva especie de Oecophyllembiinae (Lepidoptera: Gracillariidae) de Chile. Neotropical Entomology 34: 227-233.

Wagner, D. L.; J. L. Loose; T. D. Fitzgerald; J. A. de Benedicts \& D. R. Davis. 2000. A hidden past: the hypermetamorphic development of Marmara arbutiella (Lepidoptera: Gracillariidae). Annals of the Entomological Society of America 93: 59-64. 